
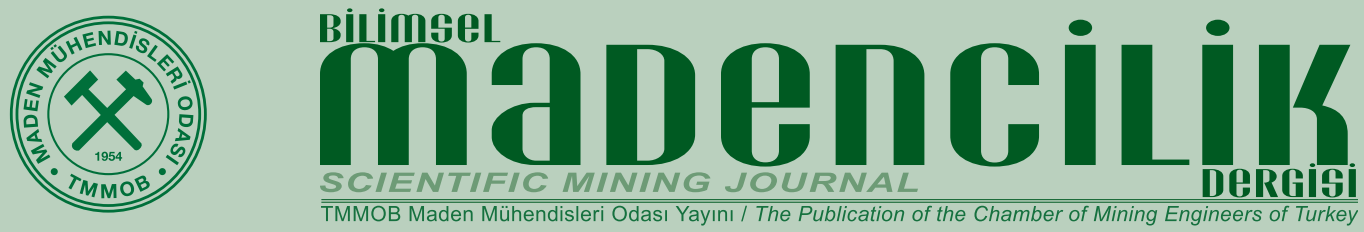

Vaka Çalışması / Case Study

\title{
CYCLE TIME SEGMENTS OF ELECTRIC ROPE SHOVELS- A CASE STUDY
} ELEKTRIKKLI HALATLI YERKAZARIN IŞ DÖNGÜSÜ EVRELERI-OLAY ÇALIŞMASI

\author{
Metin Özdoğana, ${ }^{\text {* }}$, Hakkı Özdoğana*
}

a Ideal Makina Danışmanlık Ltd. Şti., Ankara, Türkiye

$\begin{array}{ll}\text { Geliş Tarihi / Received } & : 24 \text { Nisan / April } 2018 \\ \text { Kabul Tarihi / Accepted } & : 12 \text { Eylül / September } 2018\end{array}$

Anahtar Sözcükler:

Electric rope shovel,

Cycle time and segments,

Process rate,
Dig time to cycle time ratio.

\section{ÖZ}

Monitored cycle times and cycle time segments of three $35 \mathrm{~m}^{3}$ electric rope shovels are given and discussed from a bituminous coal mine in Kuzbass Coal Basin in Siberia, based on daily monitoring reports of a four days period in May 2015. Furthermore, the results of a $45 \mathrm{~m}^{3}$ shovel operating in Northern Europe; and the results of $12 \mathrm{~m}^{3}$ and $15 \mathrm{~m}^{3}$ electric rope shovels surveyed by other researchers operating at Turkish coal mines are also given. Parameters like cycle times, cycle time segments, dig times, dig time over cycle time ratios and process rates are given and depicted, interpreted and discussed.

\section{ABSTRACT}

Keywords:

Elektrikli halatı yerkazı makinesi, İş döngüsü ve evreleri, İ̧̧lem hızı,

Kazı süresinin döngü süresine oranı.
Sibirya Kuzbass kömür havzasında, bir taşkömürü madeninde çalışan 3 adet $35 \mathrm{~m}^{3}$ kapasiteli elektikli maden yerkazarı döngü süreleri ve döngü süresini oluşturan evreleri dört gün süre ile (Mayıs 2015) günlük izleme belgelerinden izlenmiştir. Ayrıca, Kuzey Avrupa'da bir madende çalışan $45 \mathrm{~m}^{3}$ kapasiteli bir yerkazar ile Türkiye'deki kömür madenlerinde çalışan $12 \mathrm{~m}^{3}$ ve 15 $\mathrm{m}^{3}$ kepçeli elektrikli yerkazı makineleri için başka araştırmacıların sonuçları da verilmiştir. Döngü süresi, döngü süresi evreleri, kazı süreleri, kazı süresinin döngü süresine oranları verilmiş, yorumlanmış ve tartışılmıştır.

\footnotetext{
"Sorumlu yazar / Corresponding author: metinozdogan@gmail.com *https://orcid.org/0000-0001-7469-6635

*Second author: hakkiozdogan@gmail.com
} 


\section{INTRODUCTION}

Loading and hauling costs in surface mines are almost over $60 \%$ of the operating costs. These machineries perform tens of thousands of cycles annually. Therefore, a small improvement in its cycle time will definitely have a significant effect on its production and productivity. As such, it is imperative to critically analyze the cycle time operation of these machines in order to enhance the speed factor, overall effectiveness and production (Mohammad \& Rai, 2015).

For a specific electric rope shovel operating at a specific bench of a mine @ $90^{\circ}$ swing angle, swing time to truck for unloading, dump, and swing back to face to dig segments are more or less the same for the same Electric Rope Shovel (ERS) and the material being dug. These segments are governed by the technical specifications of the electric rope shovel in operation, unless smaller swing angle than $90^{\circ}$ is achieved. Generally improvement area left is the digging zone to achieve faster dig times through better fragmentation, better dipper digging and filling techniques by training the operators preferably on simulators and utilizing onboard digital smart instruments like Optidig ${ }^{\circledR}$, LoadWeigh $^{\circledR}$ which optimizes penetration and breakout forces of the dipper.

Digging and loading is the heart of any earthmoving operation. The entire system's productivity is governed by the digging and loading equipment's performance, which is mainly governed by the cycle time and dipper payload. The overall goal is to maximize profit with a digging and loading system that meets targeted hourly production at the lowest cost-per-tonne of material moved.

Focus on the analysis of the components of the cycle time may give hints on the problematic segments of the cycle time. Dig time is a function of bench geometry (bench height), rock characteristics and fragmentation, equipment design features, operator's skill and experience, rake angle etc. Swing is a function of roller circle diameter, number of swing motors and reduction ratio of gearboxes, matching truck size, operator skill and experience. Dumping phase is a function of dipper design, payload, truck spotting, stickiness of material, dumping height and skill and experience of operator. Dig phase is one of the most important segments of the cycle time (CT) which governs the dipper fill factor and payload; dig segment constitutes about $1 / 3^{\text {rd }}$ the total cycle time.

\section{THE MONITORED ELECTRIC ROPE SHOVELS IN SIBERIA}

The electric rope shovels monitored have a rated payload of 60,5 tonnes and a nominal dipper capacity of $35 \mathrm{~m}^{3}$ (Anon (b), 2016) operating at a bituminous coal mine in Kuzbass Coal Basin. Four days are examined in May 2015 for average cycle times, cycle time segments, process rates and dipper payloads, See Photograph 1 and 2. Loose unit weight of the overburden in the dipper is 1,78 tonnes per $\mathrm{m}^{3}$. Bank measure unit weight is 2,23 tonnes per $\mathrm{m}^{3}$. The electric rope shovels operated on two shifts a day basis. Day shift starts at 08.00 AM and ends at 08.00 PM, and night shift is from 08.00 PM to $08.00 \mathrm{AM}$. Cumulative operating hours on the 2800 electric rope shovels were in the range of 20,000 hours (Anon (a), 2015).

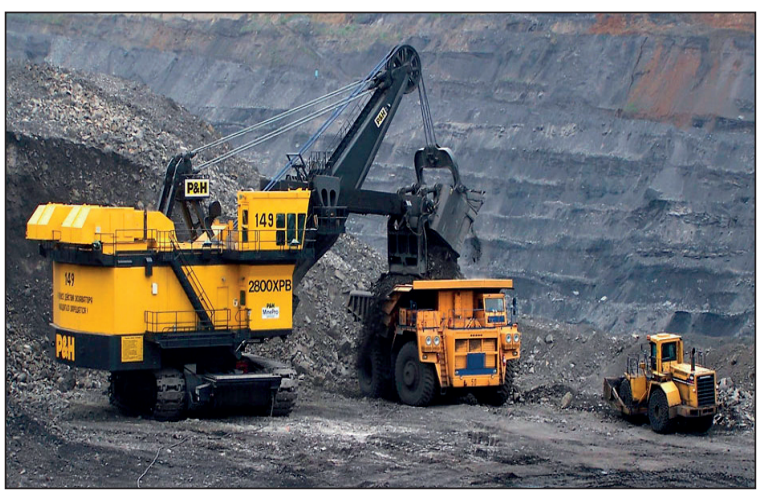

Photograph 1. Dump segment of cycle time of a $35 \mathrm{~m}^{3}$ electric rope shovel (Anon (b), 2015)

The shovels are matched with 180 tonnes and 230 tonnes Belaz trucks. The shovels fill 180 tonnes trucks in (3) three passes and fills 230 tonnes trucks in (4) four passes. The original equipment manufacturers recommend 3 to 4 passes are the best match in filling the off-highway trucks. The average dipper payloads of the electric rope shovels monitored is $58,97 \pm 0,02$ tonnes.

As the number of passes increase, production decreases while costs increase; the best number 
of dippers is around three passes where the production tonnes per hour curve and cost curve USD per tonne intersect. According to Original Equipment Manufacturer (OEM) P\&H, the optimum pass number is three (Özdoğan \& Özdoğan, 2017).

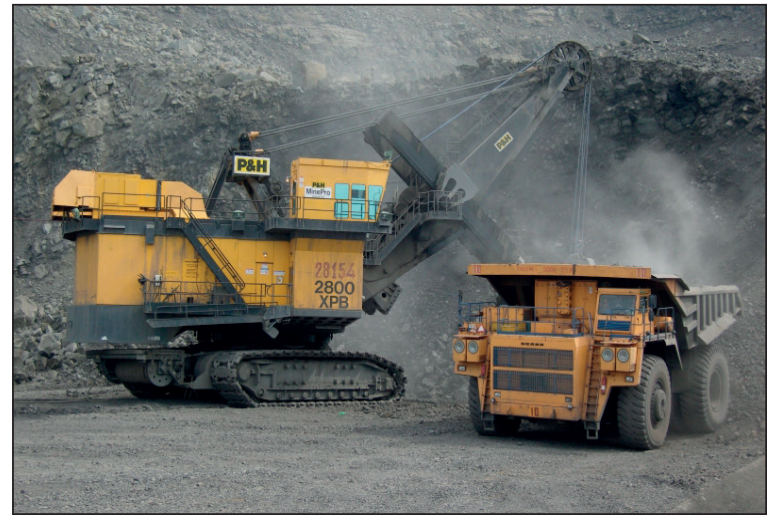

Photograph 2. Dig segment of cycle time of a $35 \mathrm{~m}^{3}$ electric rope shovel (Anon (b), 2015)

\section{CYCLE TIME SEGMENTS OF THE MONITORED ELECTRIC ROPE SHOVELS OPERATING AT KUZBASS IN SIBERIA}

One of the Key Performance Indicator of performance is the cycle time. Electrical rope shovel cycle time comprises of dig (DG), swing to dump (STDMP), dump (DMP) and swing back to face (STDG), normally. However, P\&H PrevailSystem $^{\circledast}$ progrmers preferred recording the phases as Swing Back To Dig (STDG), Dig
(DG), Swing To Dump (STDMP \& DMP) (Tuck time) segments see Table 1 . and Figures 1 and 2.

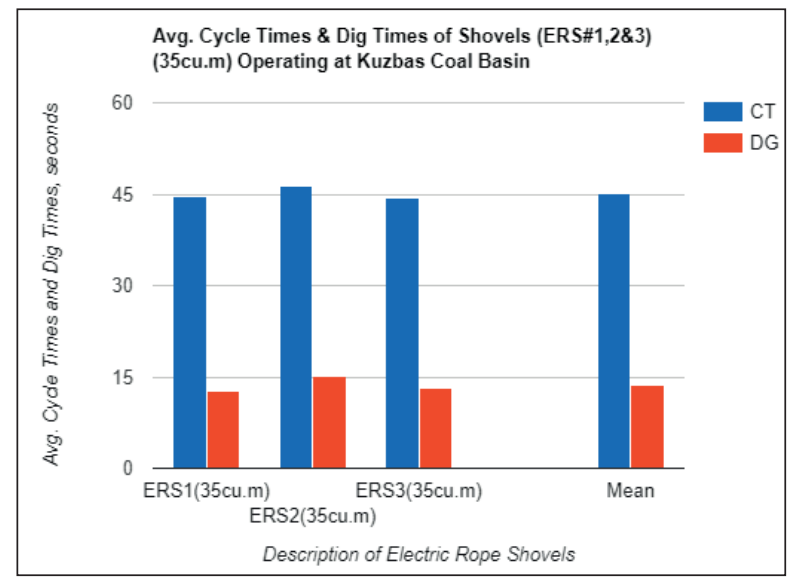

Figure 1. Average cycle and dig times of the electrical rope shovels

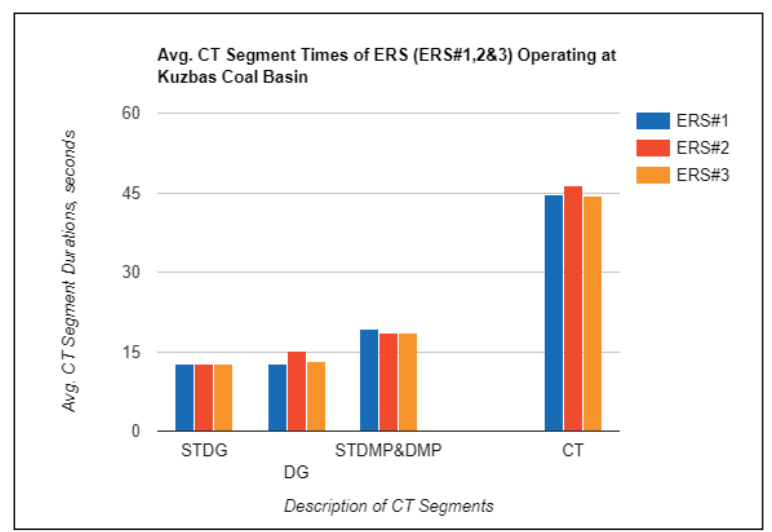

Figure 2. Cycle time segments of the monitored electric rope shovels

Table 1. DG /CT ratios and process rates (PR) of the shovels $\left(35 \mathrm{~m}^{3}\right)$ monitored at Kuzbass in Siberia

\begin{tabular}{lllll}
\hline Shovel Model & ERS \# 1 & ERS \# & ERS \# 3 & Mean \\
\hline Description $\boldsymbol{V}$ & & & & \\
STDG & $12,62 \pm 1,47$ & $12,60 \pm 2,76$ & $12,65 \pm 1,07$ & $12,62 \pm 0,02$ \\
DG & $12,72 \pm 0,29$ & $15,22 \pm 1,58$ & $13,13 \pm 0,77$ & $13,69 \pm 1,10$ \\
STDMP\&DMP & $19,35 \pm 2,75$ & $18,46 \pm 1,01$ & $18,48 \pm 1,03$ & $18,76 \pm 0,42$ \\
CT & $44,65 \pm 3,92$ & $46,34 \pm 0,88$ & $44,28 \pm 1,58$ & $45,09 \pm 0,90$ \\
DG/CT (\%) & 30 & 33 & 29 & $31 \pm 1,7$ \\
PR (CT/CT $)(\%)$ & 96 & 93 & 97 & $95 \pm 1,9$ \\
PYLD, tonnes & 59,00 & 58,95 & 58,96 & $58,97 \pm 0,02$ \\
\hline
\end{tabular}

Please note that rated cycle time of $35 \mathrm{~m}^{3}$ electric rope shovels are assumed to be 43 seconds @ $90^{\circ}$ swing angles, (Binns, 2017). 
Tucking is swing to truck to unload the dipper. It includes dumping of dipper over the truck. Swing is swing back to face to dig. Terminology of CT segments slightly vary from one researcher to another. Some researchers include dump (dipper unloading) segment into Tucking (swing to truck) and some researchers consider it as a separate segment "dump" depending on the data acquisition system and the software used. If "swing to dump" segment includes dipper unloading over the truck, then it is called "tucking"segment.

\section{CYCLE TIME SEGMENTS OF SOME OTHER ELECTRIC ROPE SHOVELS}

Ceylanoğlu (1991) made a survey on $12 \mathrm{~m}^{3}$ capacity $2100 \mathrm{BL}$ electric rope shovels in Yatağan area. The researcher explored five cases and reported the CT components in four segments. Dig (DG), swing to dump (STDMP), Dump (DMP), Swing to dig (STDG). The cycle time related parameters are given in Table 2.; Dig time, s (DG): 9,09 $\pm 0,79$; swing to dump, s (STDMP): 5,73 $\pm 0,84$; dump time, s (DMP): 4,1 $\pm 0,59$; swing to dig, $s$ (STDG): $8,27 \pm 1,04$. Average cycle time (CT) is $26,94 \pm 2,58$ seconds.

Table 2. Cycle time segments of the ERSs operating in Turkey (Modified from Ceylanoğlu \& Hindistan)

\begin{tabular}{lll}
\hline CT Segments & ERSs $\left(12 \mathrm{~m}^{3}\right)$ & ERSs $\left(15 \mathrm{~m}^{3}\right)$ \\
\hline STDG & $8,27 \pm 1,04$ & $10,39 \pm 0,89$ \\
DG, s & $9,09 \pm 0,79$ & $7,88 \pm 1,38$ \\
STDMP, s & $5,73 \pm 0,84$ & N/A \\
CT, s & $26,94 \pm 2,58$ & $28,21 \pm 3,29$ \\
DG/CT, \% & 34,00 & 28,00 \\
PR $\left(C_{\text {r }} /\right.$ CT $\left._{f}\right)$ & 93,00 & 92,00 \\
PYLD, tonnes & N/A & N/A \\
\hline
\end{tabular}

Please note that rated cycle time of $12 \mathrm{~m}^{3}$ and 15 $\mathrm{m}^{3}$ electric rope shovels are assumed to be 25 and 26 seconds @90 swing angles respectively, (Binns, 2017).

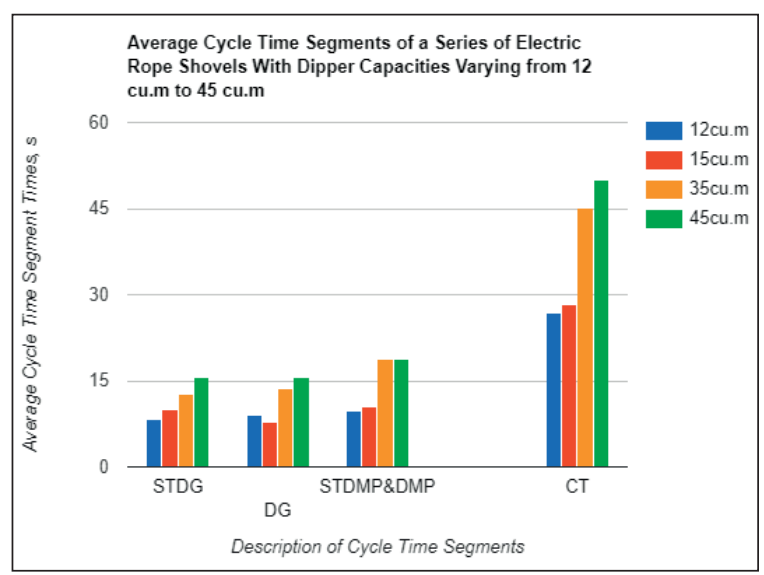

Figure 3. Cycle time segments of some electric rope shovels

Hindistan (1997) investigated $15 \mathrm{~m}^{3}$ 2300XP and M191M electric rope shovels operating at Tuncbilek, Soma and Çan coal basins for CTs and CT segments. Hindistan (1997) cites CT components in three segments. Dig (DG), swing to truck with loaded dipper (STDMP \&DMP) and swing back to face with empty dipper (STDG). Average CT of $15 \mathrm{~m}^{3}$ ERSs is $28,21 \pm 3,29$ seconds. The average CT segments are as follows: Swing to dig segment (STDG) time is $10,39 \pm 0,89$ (includes dump time) seconds; dig segment (DG) time is

$7,88 \pm 1,38$ seconds; swing to dump (STDMP) time is 9,95 $\pm 1,39$ seconds. See Table 1 and Figure 3.

Average cycle time segments of a $45 \mathrm{~m}^{3}$ electric rope shovels operating in Northern Europe is as follows: STDG segment is $15,55 \pm 0,80$ seconds, DG segment is $15,67 \pm 1,75$ seconds, STDMP \& DMP (Tuck) segment is $18,72 \pm 0,89$ seconds and CT is $49,92 \pm 2,78$ seconds. The average dipper payload of the $45 \mathrm{~m}^{3}$ shovel operating in Northern Europe is $90,70 \pm 0,00$ tonnes.

\section{DIG TIME OVER CYCLE TIME RATIOS OF ELECTRIC ROPE SHOVELS MONITORED}

Dig time is a function of bench height and diggability and hoisting characteristic of the equipment. Swing time is a function of roller circle diameter, operator skill, brake system, equipment 
design features such as number of swing motors, swing motor powers, gear box reduction ratios etc. Dig time over cycle time time ratios may be used as a measure of digging difficulty, see Figure 4. and Table 2.

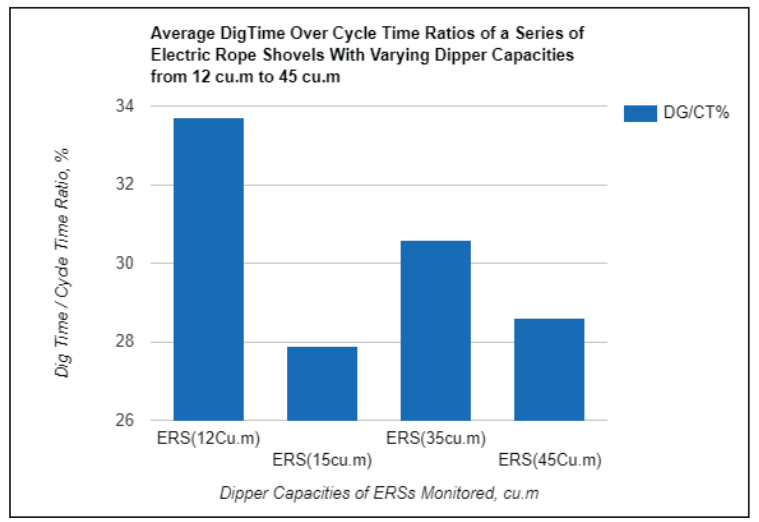

Figure 4. Average dig time/cycle time ratios of some electric rope shovels

Dig time to cycle time ratio may be considered generally as a measure of digging difficulty at the bench for one reason or another. Difficulty may be due to poor fragmentation, equipment crowd and/or hoisting problem, a problem due to the dipper teeth, rake angle, and/or an operator problem. DG/CT time ratios of $12 \mathrm{~m}^{3}$ and $15 \mathrm{~m}^{3}$ electric rope shovels are 0,337 and 0,279 respectively, see Figure 4.

Ratio of dig time segment to cycle time seems to be in the range of 30 percent, for the cases in question, see Table 2 and Figures 4 and 5 . Higher ratios than this range may indicate a bottle-neck (digging difficulty) at the face in terms of fragmentation, in the skill of the operator and/or a problem in crowd and/or hoisting systems of the electric rope shovel. Average DG/CT ratio of the $45 \mathrm{~m}^{3}$ electric shovel operating in Northern Europe is 29\% (Özdoğan \& Özdoğan, 2018), see Figure 4. above

.Swing phase time is affected by swing arc (swing angle), and the radius of the swing gear (roller circle) between the under carriage and upper frame, the number and power of swing motors, and swing gear box reduction ratio, and by the skill and experience of operator. For example, a sho- vel and truck layout with a $70^{\circ}$ swing arc has a shorter swing time than the one having $90^{\circ}$.

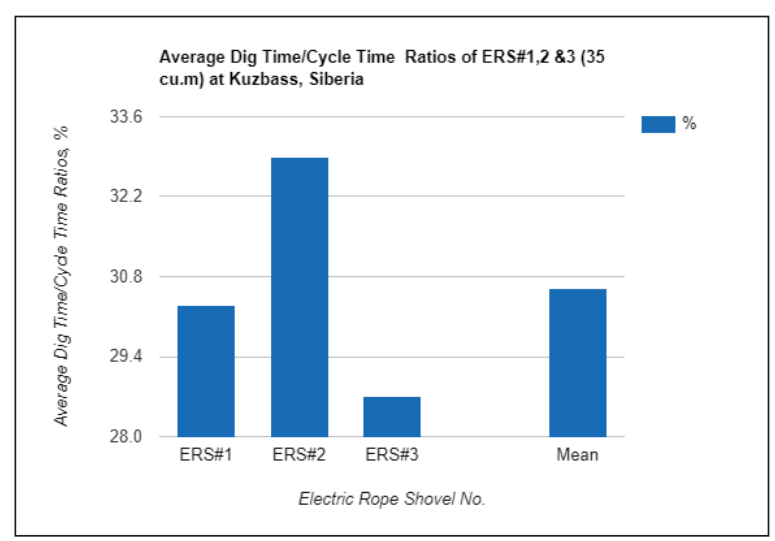

Figure 5. Dig time percentage in the cycle time of $35 \mathrm{~m}^{3}$ electric rope shovels

It is interesting to note that new generation electric rope shovels have shorter swing times with respect to total cycle times, eventhough, they have bigger roller circle to swing. This might be due to the fact that the new generation ERSs usually have a third swing motor and gear box to have faster swing times. The old generation ERSs had only two swing motors traditionally.

\section{PROCESS RATES OF THE ELECTRIC ROPE SHOVELS}

Process rate is the ratio of the planned cycle time of the equipment to actual cycle time. It indicates the deviation of actual CT (field CT) from planned cycle time (rated CT). Process rate primarily depends on the system characteristics and related human factors. Mathematically it can be expressed as $\mathrm{CT}_{\mathrm{r}} / \mathrm{CT}_{\mathrm{f}}$. Process rate is an indicator that manufacturers use for performance measurement of their industry as a component of Overall Equipment Effectiveness (OEE) (Mohammad \& Rai, 2015).

Information on rated cycle times of $35 \mathrm{~m}^{3}$ and 45 $\mathrm{m}^{3}$ electric rope shovels are obtained from the original equipment manufacturer. Please note that rated cycle time of $45 \mathrm{~m}^{3}$ electric rope shovels are assumed to be 45 seconds @ $90^{\circ}$ swing angles, (Binns, 2017). 
Cycle time phases are functions of ERS's parameters, design features of equipment age and specifications, dipper and truck match parameters, operator parameters, bench geometry and rock diggability (loadability) characteristics of ERS and rock material, rock blasting and fragmentation parameters, in general.

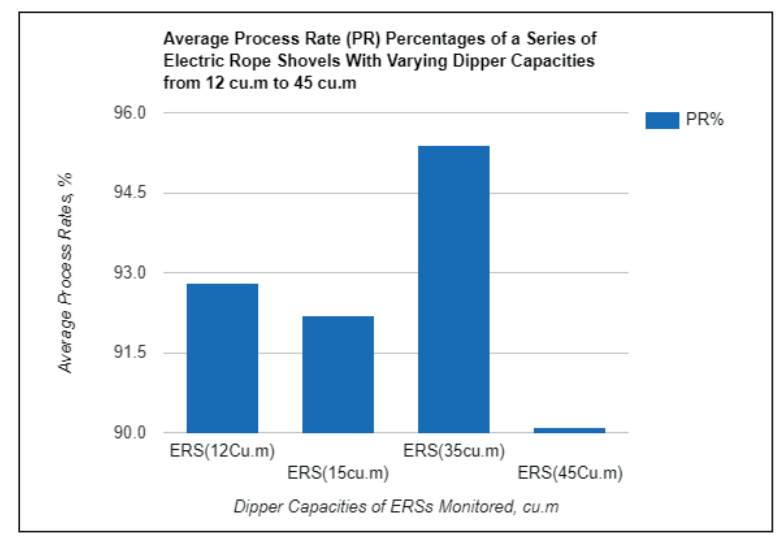

Figure 6. Process rates of the electric rope shovels monitored

Average process rates of the $12 \mathrm{~m}^{3}$ and $15 \mathrm{~m}^{3}$ electric rope shovels operating in Turkey are 0,928 and 0,922 respectively, see Table 2 .

\section{CONCLUSIONS}

The major factor influencing the total cycle times of the shovel is the average dig times, as expected, as long as the swing angle and the truck shovel layout do not change with respect to the bench face. Swing and dumping phase times do not vary much since @ $90^{\circ}$ swing angle. Because of the fact that they are the design features of the equipment which do not vary much as long as the operator is trained, skilled and experienced. Therefore, dig time duration is the main factor influencing the total cycle time of the equipment as long as the dipper fill factors are favorable and consistent.

Cycle time segments and cycle time are impacted by equipment parameters, shovel and truck match parameters, operator parameters, bench geometry and rock parameters, diggability (loadability) and rock blasting and fragmentation parameters, in general.
Average cycle time segments of the three electric rope shovels $\left(35 \mathrm{~m}^{3}\right)$ monitored are as follows: Swing to dig segment time is $12,62 \pm 0,02$ seconds; Dig segment time is $13,69 \pm 1,10$ seconds; Tucking segment time is $18,76 \pm 0,42$ and cycle time is $45,09 \pm 0,90$ seconds. Cycle time is the major performance indicator of both the operator and the electric rope shovel. Focusing on the analysis of the components of the cycle time is of supreme importance in improving cycle time. Another major productivity indicator is the dipper payload. The cycle time secured may be good, shorter, however, if the bucket is not filled to the designated target load, it is waste of time and money. Therefore, shovels should be equipped with onboard load weighing systems. Average dipper payloads of the three electric shovels monitored is $58,97 \pm 0,02$ tonnes. The average dipper payload of the $45 \mathrm{~m}^{3}$ shovel operating in Northern Europe is $90,70 \pm 0,00$ tonnes. Average dig time over cycle time ratios of the three $35 \mathrm{~m}^{3}$ electric rope shovels monitored is $0,306 \pm 0,017$. As far as the cases monitored reveal for an optimum electric rope shovel operation, the dig time is about one third of the cycle time Average process rate for the three $35 \mathrm{~m}^{3}$ electric mining shovels monitored is $0,954 \pm 0,019$.

The facts and figures cited here in the text to be only considered as guidelines, because of the fact that there are so many factors influencing the production and performance of electric rope shovels. These factors may be classified as the ones related to minesite, equipment, human, administration, environment, collective bargaining agreements of labour unions which includes brakes like tea, coffee and lunch.

\section{REFERENCES}

Anon (a), 2018. P\&H PrevailSystem ${ }^{\circledast}$ Reports, U.K.

Anon (b), 2016. http://www.joyglobal.com/productdetails/2800xpc

Binns, D., 2017. Personal communication, Plymouth, England.

Ceylanoğlu, A., 1991. Performance Monitoring of Electrical Power Shovels for Diggability Assessment in 
Surface Coal Mines. Ph.D. Thesis, METU, Ankara, July 1991 (Unpublished Ph.D. Dissertation).

Hindistan, M. A., 1997. Development of a Computer Based monitoring System and Its Usage for Power Shovels' Monitoring. Ph.D. Thesis, METU, Ankara, November 1991 (Unpublished Ph.D. Dissertation).

Mohammadi, M., Rai, P., 2015. Improving Performance of Mining Equipment Through Enhancement of Speed Factor- A Case Study. Intl. Journal of Engineering, IJE Transactions C: Aspects, Vol.28, No:9, September 2015.
Özdoğan, M., Özdoğan, H., 2017. Field Performance of a New Generation $35 \mathrm{~m}^{3}$ Range Electric Rope Shovel (2800XPB) - A Case Study. Proceedings Book of $25^{\text {th }}$ IMCET Congress, 11-14 April, 2017, Antalya, Turkey.

Özdoğan, M., Özdoğan, H., 2018. Field Performance of a New Generation $45 \mathrm{~m}^{3}$ Range Electric Rope Shovel $(4100 C)$ - A Case Study. https://www.researchgate. net/publication/318440839_FIELD_PERFORMANCE_ OF_A_NEW_GENERATION_45_m_3_RANGE_ ELECTRIC_ROPE_SHOVEL-PH4100C-A_Case_ Study. 